\title{
Natronomonas salsuginis sp. nov., a New Inhabitant of a Marine Solar Saltern
}

\author{
Ana Durán-Viseras, Cristina Sánchez-Porro $\mathbb{D}$ and Antonio Ventosa * (D)
}

Department of Microbiology and Parasitology, Faculty of Pharmacy, University of Sevilla, 41012 Sevilla, Spain; anaduran@us.es (A.D.-V.); sanpor@us.es (C.S.-P.)

* Correspondence: ventosa@us.es; Tel.: +34-954556765

Received: 21 March 2020; Accepted: 19 April 2020; Published: 21 April 2020

Abstract: A halophilic archaeon, strain F20-122 ${ }^{\mathrm{T}}$, was isolated from a marine saltern of Isla Bacuta (Huelva, Spain). Cells were Gram-stain-negative, aerobic, and coccoid in morphology. It grew at $25-50{ }^{\circ} \mathrm{C}$ (optimum $37^{\circ} \mathrm{C}$ ), $\mathrm{pH} 6.5-9.0$ (optimum pH 8.0), and 10-30\% (w/v) total salts (optimum $25 \%$ salts). The phylogenetic analyses based on the $16 \mathrm{~S}$ rRNA and $r p o B^{\prime}$ genes showed its affiliation with the genus Natronomonas and suggested its placement as a new species within this genus. The in silico DNA-DNA hybridization (DDH) and average nucleotide identity (ANI) analyses of this strain against closely related species supported its placement in a new taxon. The DNA G + C content of this isolate was $63.0 \mathrm{~mol} \%$. The polar lipids of strain $\mathrm{F} 20-122^{\mathrm{T}}$ were phosphatidylglycerol phosphate methyl ester (PGP-Me), phosphatidylglycerol (PG), and phosphatidylglycerol sulfate (PGS). Traces of biphosphatidylglycerol (BPG) and other minor phospholipids and unidentified glycolipids were also present. Based on the phylogenetic, genomic, phenotypic, and chemotaxonomic characterization, we propose strain F20-122 ${ }^{\mathrm{T}}\left(=\mathrm{CCM} 8891^{\mathrm{T}}=\mathrm{CECT} 9564^{\mathrm{T}}=\mathrm{JCM} 33320^{\mathrm{T}}\right)$ as the type strain of a new species within the genus Natronomonas, with the name Natronomonas salsuginis sp. nov. Rhodopsin-like sequence analysis of strain F20-122 ${ }^{\mathrm{T}}$ revealed the presence of haloarchaeal proton pumps, suggesting a light-mediated ATP synthesis for this strain and a maximum wavelength absorption in the green spectrum.

Keywords: Haloarchaea; hypersaline habitats; taxonomy; Natronomonas; rhodopsins

\section{Introduction}

The genus Natronomonas belongs to the family Haloarculaceae, within the order Halobacteriales, class Halobacteria in the phylum Euryarchaeota. The type species of the genus is Natronomonas pharaonis, which was isolated from alkaline brines in Egypt [1]. This species was first described as Halobacterium pharaonis [1]. After that, it was transferred to the genus Natronobacterium as Natronobacterium pharaonis [2], and finally, Kamekura et al. [3] proposed the transfer of Natronobacterium pharaonis to the new genus Natronomonas based on its $16 \mathrm{~S}$ rRNA sequence similarity. At the time of writing, the genus Natronomonas comprises two other described species [4] —Natronomonas moolapensis [5] and Natronomonas gomsonensis [6] —which were isolated from marine salterns of Australia and Korea, respectively.

One of the particular features of this genus is that it comprises alkaliphilic and nonalkaliphilic species. While Natronomonas moolapensis and Natronomonas gomsonensis are nonalkaliphilic, the type species of the genus, Natronomonas pharaonis, is able to grow between $\mathrm{pH}$ values of 8.0 and 11.0, with the optimum at $\mathrm{pH}$ 8.5-9.0, being the first alkaliphilic extreme halophile described. The genus Natronomonas comprises motile and Gram-stain-negative species with a wide variety of cell morphologies, from short rods to coccoid-shaped or flat tetragonal shapes [5,6]. Other characteristics of species of this genus are their red-pigmented colonies and an aerobic and chemo-organotrophic metabolism $[5,6]$. The species of the genus Natronomonas are halophilic, which require at least $2 \mathrm{M} \mathrm{NaCl}$ for growth. The major polar 
lipids are phosphatidylglycerol, phosphatidylglycerophosphate methyl ester, and phosphatidic acid. Undetermined phospholipids or glycolipid may exist and phytanyl-sesterpanyl moieties $\left(\mathrm{C}_{20} \mathrm{C}_{25}\right)$ are also present [5]. The DNA G + C content of the strains ranged from 61.8 to $64.3 \mathrm{~mol} \%[3,5,6]$.

The genus Natronomonas is one of the oldest and best known haloarchaeal genera. Their rhodopsins and their applications have been deeply studied. Besides, several studies have focused on the biotechnological potential of its enzymes [7-15]. On the other hand, several culture-independent studies have also shown the presence of members of the genus Natronomonas in different environments from widely separated sites, such as hypersaline and alkaline lakes, solar salterns, saline-alkaline soils, and sediments or oil fields [16-31], supporting the widespread distribution of species of this genus.

During the course of the study of the prokaryotic diversity inhabiting various hypersaline environments of southwest Spain, a new haloarchaeon, designated strain F20-122 ${ }^{\mathrm{T}}$, was isolated in pure culture. Based on the $16 \mathrm{~S}$ rRNA gene sequence analysis, this strain was phylogenetically related to species of the genus Natronomonas. In this paper, we describe the isolation and taxogenomic characterization of this archaeon and propose it as a new species of the genus Natronomonas, for which we propose the name Natronomonas salsuginis sp. nov.

\section{Materials and Methods}

\subsection{Isolation, Culture, and Preservation of Haloarchaeal Strain}

Strain F20-122 ${ }^{\mathrm{T}}$ was isolated from a water sample obtained in June 2016 from a pond of a marine saltern located in Isla Bacuta, Huelva, southwest coast of Spain $\left(37^{\circ} 15^{\prime} \mathrm{N} 6^{\circ} 58^{\prime} \mathrm{W}\right)$. At the time of sampling, the salinity of the water was $17 \%(w / v)$ and the $\mathrm{pH}$ was 7.8 . Samples were collected in sterile containers, transported to the laboratory, and plated under sterile conditions. Plates were incubated at $37^{\circ} \mathrm{C}$ for up to 3 months. Strain F20-122 ${ }^{\mathrm{T}}$ was isolated in pure culture after three successive cultivations on R2A medium (Difco) supplemented with $25 \%$ seawater salts solution, with the following composition ( $\mathrm{g} \mathrm{L}^{-1}$ ): $\mathrm{NaCl}, 195 ; \mathrm{MgCl}_{2} .6 \mathrm{H}_{2} \mathrm{O}, 32.5 ; \mathrm{MgSO}_{4} .7 \mathrm{H}_{2} \mathrm{O}, 50.8 ; \mathrm{CaCl}_{2}, 0.83 ; \mathrm{KCl}, 5.0 ; \mathrm{NaHCO}_{3}$, $0.21 ; \mathrm{NaBr}, 0.58$. The $\mathrm{pH}$ was adjusted to 7.5 with $1 \mathrm{M} \mathrm{KOH}$. Purified agar (2\%; Oxoid) was used as a solidifying agent. Strain F20-122 ${ }^{\mathrm{T}}$ was routinely grown in the same medium of isolation (designated $\mathrm{R} 2 \mathrm{~A} 25 \%$ ) and incubated aerobically at $37^{\circ} \mathrm{C}$ for 14 days, using a rotary shaker for growth in liquid medium. Cultures were maintained at $-80^{\circ} \mathrm{C}$ in R2A25\% medium containing $25 \%(v / v)$ glycerol for long-time preservation. The type strains Natronomonas moolapensis CECT $7526^{\mathrm{T}}$ and Natronomonas pharaonis CECT $4578^{\mathrm{T}}$ were used as reference strains for comparative purposes in our study.

\subsection{DNA Extraction, Purification, and Sequencing}

Using the method described by Marmur [32], the genomic DNA from strain F20-122 ${ }^{\mathrm{T}}$ was extracted and purified for $16 \mathrm{~S}$ rRNA and $r p o B^{\prime}$ gene analysis and for genome sequencing. The quality of the DNA was checked by (1\%) agarose gel electrophoresis. DNA quantification was determined by spectrophotometry (DeNovix DS-11 FX, DeNovix Technologies, Wilmington, Delaware, USA) and fluorometry (Qubit 3.0 Fluorometer, Thermofisher Scientific, USA). The 16S rRNA and rpoB' genes were amplified by PCR [33] with the universal primers ArchF and ArchR [34,35] and the primers designed by Fullmer et al. [36], respectively. The PCR products were sequenced by StabVida (Oeiras, Portugal) using the Sanger method and the same primers. For the 16S rRNA gene sequencing, primers 16RB36 (GGA CTA CCA GGG TAT CTA) and 16RD34 (GGT CTC GCT CGT TGC CTG) were also used. Sequencing reactions were carried out using a BigDye terminator kit version 3.1 from Applied Biosystems. A draft genome sequence of strain F20-122 ${ }^{\mathrm{T}}$ was also determined in this study using a whole-genome shotgun strategy. After the DNA quality control, a library was constructed using the Kappa HyperPrep library preparation kit. The generated DNA libraries were sequenced in the lllumina Hiseq 4000 platform, using 150 bp paired-end sequencing reads (StabVida, Oeiras, Portugal). 


\subsection{Phylogenetic Analyses}

The $16 \mathrm{~S}$ rRNA and $r p o B^{\prime}$ gene sequences of strain $\mathrm{F} 20-122^{\mathrm{T}}$ were aligned with ChromasPro (Technelysium Pty Ltd.) software version 1.5 and deposited in GenBank/EMBL/DDBJ under the accession numbers MH424601 and MH454090, respectively. The identification of phylogenetic neighbors and the calculation of pairwise $16 \mathrm{~S}$ rRNA and $r p o B^{\prime}$ gene sequence similarities were achieved using the EzBioCloud tool [37] and BLAST [38], respectively. The 16S rRNA gene sequence analysis and phylogenetic tree reconstructions were performed with the ARB software package [39]. Phylogenetic trees were inferred using three different methods-maximum-parsimony [40], neighbor-joining [41], and maximum-likelihood [42] algorithms-integrated in the ARB software. A bootstrap analysis (1000 replications) was performed to evaluate the robustness of the phylogenetic trees [43]. For the construction of the trees based on the rpoB' gene sequence, MEGA 6.0 software was used with the neighbor-joining and maximum-likelihood algorithms [44]. The 16S rRNA and $r p o B^{\prime}$ gene sequences used for phylogenetic comparisons were obtained from the GenBank database. For the phylogenomic core genome analysis reconstruction, all-versus-all BLAST search [38] was used for comparisons of all predicted protein-coding genes annotated from each available genome. MUSCLE [45] was used for the individual alignment of the core orthologous genes with diagonal optimization and adjusting to the maximum number of iterations (default values for the other parameters). The phylogenomic tree was reconstructed by using MEGA 6.0 software (neighbor-joining method with Jukes-Cantor correction) [44]. For the Venn diagram representation, the online software InteractiVenn was used [46].

\subsection{Genome Assembly, Annotation, and Determination of Genomic Parameters}

For the de novo assembly of the reads, Spades v.3.12.0. [47] was used. CheckM v1.0.5 [48] and Quast v2.3 [49] were utilized to assess the quality of the final contigs. The genome sequence of strain F20-122 ${ }^{\mathrm{T}}$ was annotated using the NCBI Prokaryotic Genome Annotation Pipeline (PGAP) [50] and deposited in GenBank/EMBL/DDBJ under the accession number QKNX00000000.

The genomic parameters average nucleotide identity (ANI) and in silico DNA-DNA hybridization $(\mathrm{DDH})$ between the genome of the strain $\mathrm{F} 20-122^{\mathrm{T}}$ and the genomes of Natronomonas pharaonis DSM $2160^{\mathrm{T}}$ (GCF_000026045) and Natronomonas moolapensis 8.8.11 ${ }^{\mathrm{T}}$ (GCF_000591055) were calculated by using OAT software v0.93.1 [51] and the Genome-to-Genome Distance Calculator (GGDC) [52] website, using formula 2 [53], respectively.

\subsection{Phenotypic Characterization}

Phenotypic tests were performed according to the proposed minimal standards for the description of novel taxa in the class Halobacteria [54]. Natronomonas moolapensis CECT $7526^{\mathrm{T}}$ was used in this study for comparison as a reference strain. Natronomonas pharaonis CECT $4578^{\mathrm{T}}$, the type species of the genus, was not included on the phenotypic comparison because it grows at a markedly different $\mathrm{pH}$ compared with strain F20-122 ${ }^{\mathrm{T}}$.

Strain F20-122 ${ }^{\mathrm{T}}$ was grown on R2A25\% medium on a shaking incubator at $200 \mathrm{rpm}$ for the determination of cellular morphology and motility. The cells were examined by light microscopy under a phase-contrast microscope (Olympus BX41). Gram staining was carried out using acetic-acid-fixed samples as described by Dussault [55]. For anaerobic tests, R2A25\% plates supplemented with $4 \%$ L-arginine, $10 \% \mathrm{DMSO}$, and $3 \% \mathrm{KNO}_{3}$, respectively, were inoculated and incubated at $37{ }^{\circ} \mathrm{C}$ in an anaerobic chamber (Oxoid) for 21 days. The morphology of the colonies of strain F20-122 ${ }^{\mathrm{T}}$, their size, and pigmentation were observed on R2A25\% medium up to 14 days of aerobic incubation at $37^{\circ} \mathrm{C}$. The range and optimal conditions of salinity for growth was determined by using R2A liquid medium supplemented with $0.9,3,5,10,15,20,25$, and $30 \%(w / v)$ total salts. In order to determine the $\mathrm{pH}$ range (and optimum) for growth of strain $\mathrm{F} 20-122^{\mathrm{T}}$, the isolate was cultured under the optimal salt concentration conditions, adjusting the medium to $\mathrm{pH}$ 5.0, 6.0, 6.5, 7.0, 7.5, 8.0, 8.5, 9.0, and 10.0 with 
the addition of the appropriate buffers [56]. The optimal and range of temperature were determined by incubating strain $\mathrm{F} 20-122^{\mathrm{T}}$ under the optimal salt concentration and $\mathrm{pH}$ conditions, at temperatures of $4,15,20,25,30,37,40,45,50,55$, and $60^{\circ} \mathrm{C}$. Growth rates were determined by monitoring the increase in the optical density at $600 \mathrm{~nm}$.

Catalase activity was determined by adding a 3\% $(w / v) \mathrm{H}_{2} \mathrm{O}_{2}$ solution to colonies on $\mathrm{R} 2 \mathrm{~A} 25 \%$ medium. Oxidase activity was examined with $1 \%(v / v)$ tetramethyl-p-phenylenediamine [57]. All biochemical tests were carried out in $\mathrm{R} 2 \mathrm{~A} 25 \%$ medium $(\mathrm{pH} 7.5)$ at $37{ }^{\circ} \mathrm{C}$, unless otherwise stated. Hydrolysis of aesculin, gelatin, or starch was carried out as described by Barrow and Feltham [58]. Tests for indole production from tryptophan and urease test were performed as described by Gerhardt et al. [59]. Voges-Proskauer and methyl red tests were determined as described by Oren et al. [54]. The reduction of nitrate and nitrite were detected by using sulfanilic acid and $\alpha$-naphthylamine reagents [60]. $\mathrm{H}_{2} \mathrm{~S}$ formation was determined following the methodology described by Clarke [61]. Citrate utilization was determined on Simmons' citrate medium supplemented with a $25 \%$ seawater salts solution (SW25) [54]. Acid production from carbohydrates was determined using a modified phenol red base medium prepared with SW25 solution supplemented with $0.5 \%(w / v)$ yeast extract (Difco) and 1\% (w/v) of the carbohydrate [54]. To assess the utilization of sole carbon and energy sources, $1 \%(w / v)$ of different carbohydrates, alcohols, amino acids, and organic acids substrates were added individually in SW25 solution containing 0.05\% (w/v) yeast extract (Difco) [62]. Substrates were added as filter-sterilized solutions to give a final concentration of $1 \mathrm{~g} \mathrm{~L}^{-1}$ for organic acids and amino acids, and of $2 \mathrm{~g} \mathrm{~L}^{-1}$ for carbohydrates and alcohols.

\subsection{Chemotaxonomic Analysis}

Polar lipids of strain F20-122 ${ }^{\mathrm{T}}$, Natronomonas pharaonis CECT $4578^{\mathrm{T}}$, and Natronomonas moolapensis CECT $7526^{\mathrm{T}}$ were obtained from biomass cultured in medium R2A25\% at $37^{\circ} \mathrm{C}$ for 14 days for strain F20-122 ${ }^{\mathrm{T}}$ and Natronomonas moolapensis CECT $7526^{\mathrm{T}}$ and from biomass cultured in the alkaline medium for Natronomonas pharaonis CECT $4578^{\mathrm{T}}$ [1]. Halobacterium salinarum DSM $3754^{\mathrm{T}}$ and Halorubrum saccharovorum DSM $1137^{\mathrm{T}}$ were used as reference species for polar lipid characterization. Polar lipids were extracted with chloroform/methanol following the method for extraction of membrane polar lipids of halophilic archaea described previously by Corcelli and Lobasso [63]. Total lipid extracts were analyzed by high-performance thin layer chromatography (HPTLC), using HPTLC silica gel 60 plates crystal back (10,620 cm; Merck art. 5626); the plates were developed in the solvent system chloroform/methanol/90\% acetic acid (65:4:35) [64]. To detect all polar lipids, the plate was sprayed with $5 \%$ sulfuric acid in water and charred by heating at $160{ }^{\circ} \mathrm{C}$ [65]. To identify phospholipids, another HPTLC was performed and sprayed with molybdenum blue reagent, which selectively stains phospholipids.

\subsection{Rhodopsin Analysis}

Hmmsearch [66] and a profile hidden Markov model (HMM) of the bacteriorhodopsin-like protein family (Pfam accession: PF01036) were used to explore the presence of rhodopsin-like sequences in the genomes of strain F20-122 ${ }^{\mathrm{T}}$, Natronomonas pharaonis DSM $2160^{\mathrm{T}}$, and Natronomonas moolapensis 8.8.11 ${ }^{\mathrm{T}}$. To align the identified sequences and a curated database based on type- 1 rhodopsins, MAFFT with the L-INS-i accuracy model [67] was employed. For the rhodopsin tree reconstruction, FastTree2 software [68] (maximum-likelihood algorithm and 100 bootstrap replicates) was used.

\section{Results and Discussion}

\subsection{Phylogenetic Analyses}

From a study of prokaryotic diversity in different hypersaline habitats of southwest Spain, an extensive collection of haloarchaeal strains were recovered, including strain F20-122 ${ }^{\mathrm{T}}$, which was isolated in pure culture and selected for further analyses. 
The almost-complete 16S rRNA gene sequence analysis of strain F20-122 ${ }^{\mathrm{T}}(1,400 \mathrm{bp})$ showed that it was closely related to members of the genus Natronomonas. The highest sequence similarity values were to the 16S rRNA genes of Natronomonas moolapensis $8.8 .11^{\mathrm{T}}(97.7 \%)$, Natronomonas pharaonis DSM $2160^{\mathrm{T}}(97.4 \%)$, and Natronomonas gomsonensis SA3 ${ }^{\mathrm{T}}(96.1 \%)$. The $16 \mathrm{~S}$ rRNA gene sequence similarity with species of other genera, such as Salinirubellus or Halomarina, was always equal or lower than 90.7\%. The 16S-rRNA-based phylogenetic tree constructed by maximum parsimony (Figure 1) showed that strain $\mathrm{F} 20-122^{\mathrm{T}}$ clustered with the three species of the genus Natronomonas but was placed in an independent branch with a bootstrap value of $100 \%$. This topology suggests that the new strain F20-122 $2^{\mathrm{T}}$ could constitute a new member of the genus Natronomonas. Trees with similar topology were obtained using the neighbor-joining or maximum-likelihood algorithms (Figure 1).

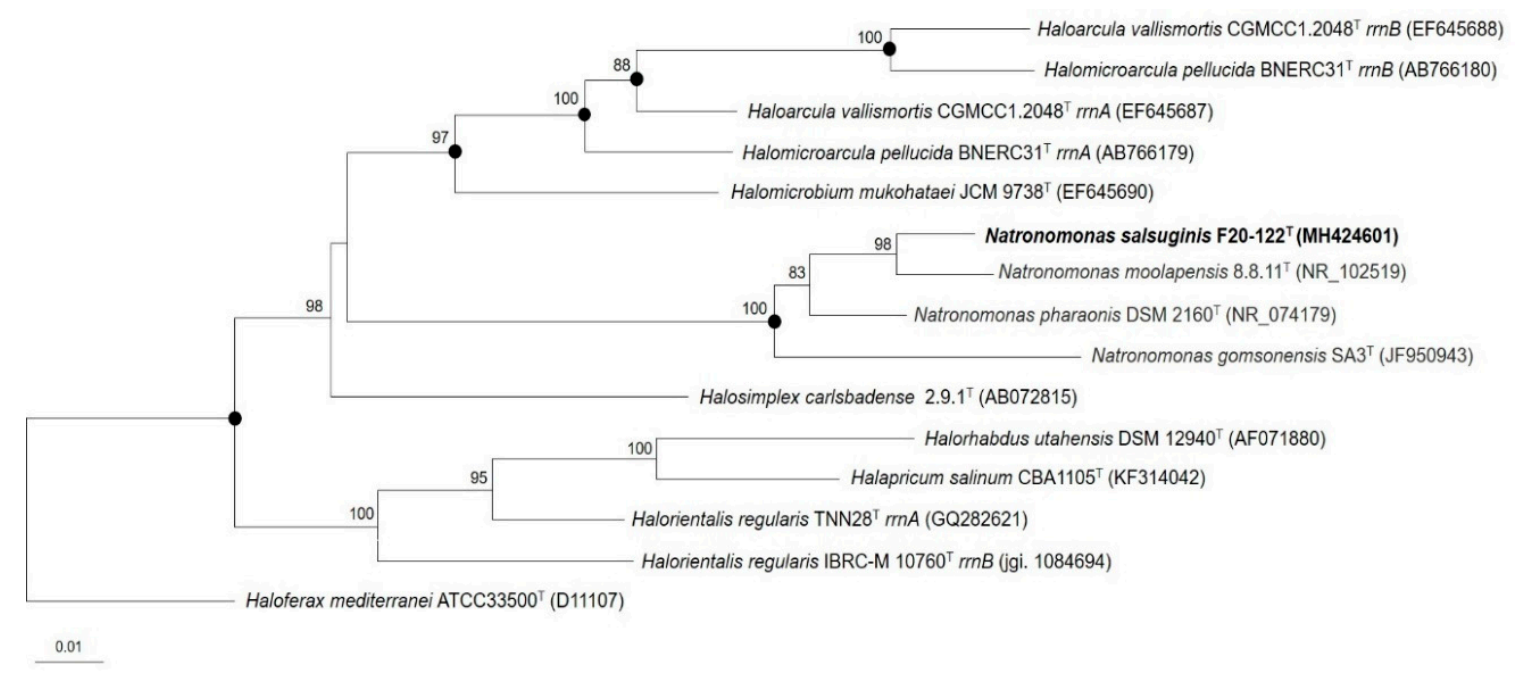

Figure 1. Maximum-parsimony phylogenetic tree reconstruction based on the 16S rRNA gene sequence comparison showing the phylogenetic position of strain $\mathrm{F} 20-122^{\mathrm{T}}$ and the closely related species of the genus Natronomonas and other related genera. Sequence accession numbers are shown in parentheses. Bootstrap values higher than $70 \%$ are indicated at branch points. Filled circles indicate that the corresponding nodes were also obtained in the trees generated with the neighbor-joining and maximum-likelihood algorithms. The species Haloferax mediterranei ATCC $33500^{\mathrm{T}}$ was used as an outgroup. Bar, 0.01 substitutions per nucleotide position.

To avoid the limitations of using only the 16S rRNA gene [69,70], other phylogenetic approaches should additionally be used. Thus, the $r p o B^{\prime}$ gene sequence of strain $\mathrm{F} 20-122^{\mathrm{T}}(611 \mathrm{bp})$ was also obtained and compared with those of the most closely related species. The phylogenetic tree analysis based on this gene by using the neighbor-joining algorithm showed that strain F20-122 ${ }^{\mathrm{T}}$ also clustered with the three species of the genus Natronomonas (Figure 2) but constituted a monophyletic branch clearly separated from those of the already described species, supporting its condition of a new taxon. Again, the topology of the tree constructed using the maximum-likelihood algorithm was in concordance with the neighbor-joining one. 


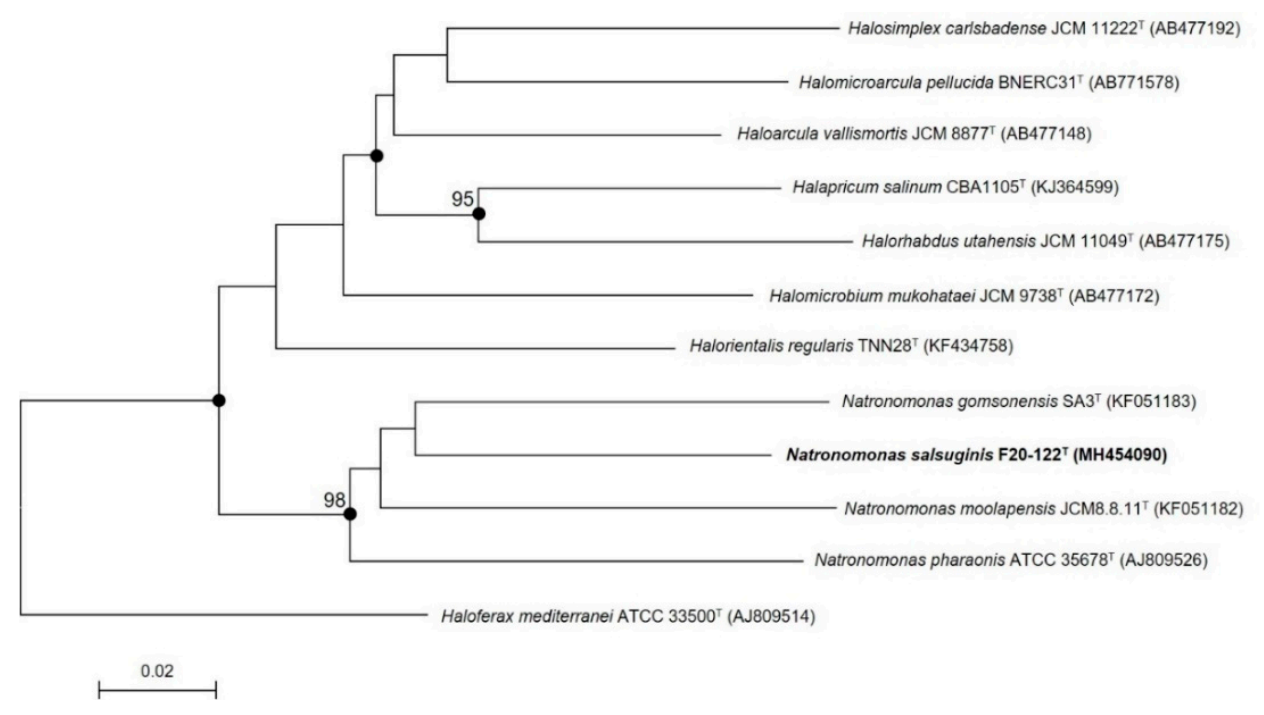

Figure 2. Phylogenetic tree reconstruction based on the $r p o B^{\prime}$ gene of strain $\mathrm{F} 20-122^{\mathrm{T}}$ and related species based on neighbor-joining algorithm. Sequence accession numbers are shown in parentheses. Bootstrap values higher than $70 \%$ are indicated at branch points. Filled circles indicate that the corresponding nodes were also obtained in the trees generated with the neighbor-joining and maximum-likelihood algorithms. The species Haloferax mediterranei ATCC $3350^{\mathrm{T}}$ was used as an outgroup. Bar, 0.02 substitutions per nucleotide position.

In addition, a reconstruction of the phylogenetic core genome analysis was performed. The phylogenomic tree reconstruction (Figure 3), based on the alignment of 319 single-copy orthologous genes shared by all strains, revealed again that strain $\mathrm{F} 20-122^{\mathrm{T}}$ formed a clade with Natronomonas pharaonis DSM $2160^{\mathrm{T}}$ and Natronomonas moolapensis $8.8 .11^{\mathrm{T}}$ with a bootstrap value of $100 \%$ but clustered in a different branch well separated from them with a bootstrap value of $100 \%$, reinforcing its condition of a new taxon within the genus Natronomonas.

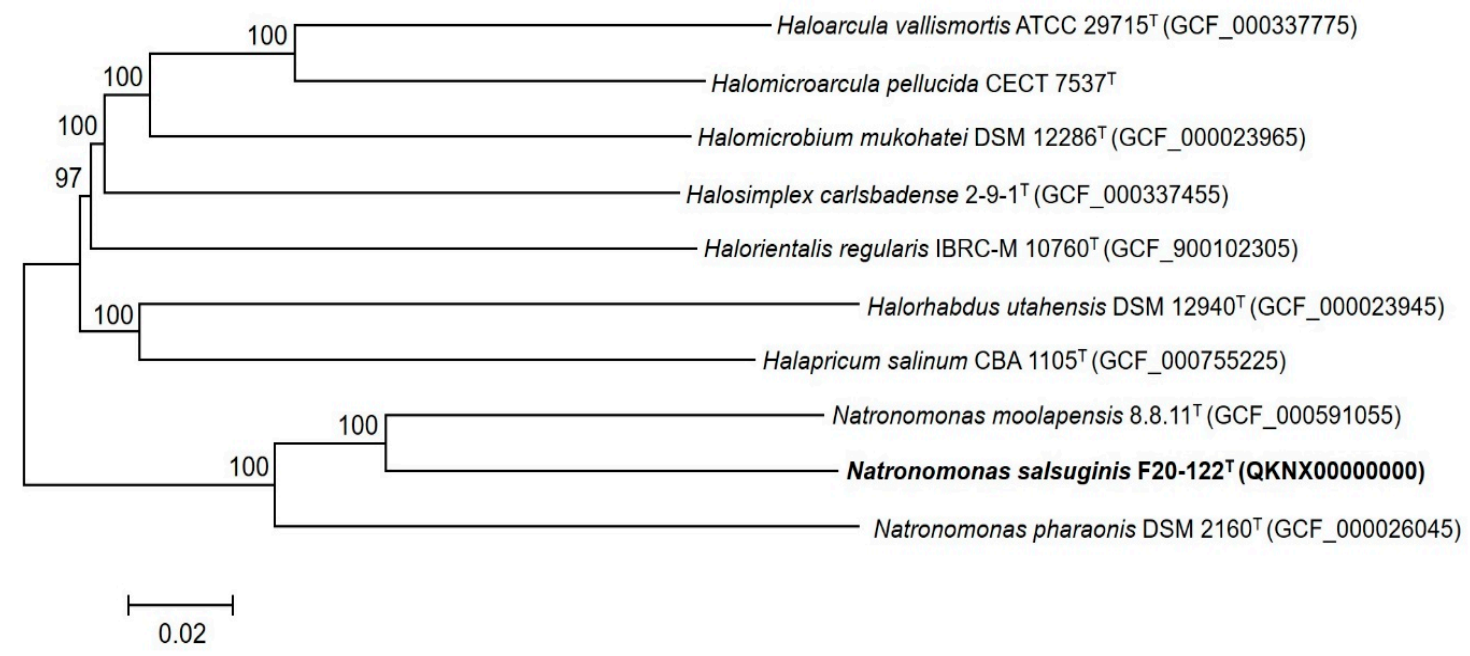

Figure 3. Phylogenomic tree reconstruction based on the core orthologous genes of strain $\mathrm{F} 20-122^{\mathrm{T}}$ and related species based on the neighbor-joining algorithm. This tree was obtained after the alignment of 319 shared orthologous single-copy genes of these genomes. Bootstrap values higher than $70 \%$ are indicated at branch points. Bar, 0.02 substitutions per nucleotide position.

In order to confirm if strain $\mathrm{F} 20-122^{\mathrm{T}}$ would constitute a new species within the genus Natronomonas, the genomic parameters ANI and in silico DDH were estimated. The OrthoANI values between strain 
F20-122 ${ }^{\mathrm{T}}$, Natronomonas pharaonis DSM $2160^{\mathrm{T}}$, and Natronomonas moolapensis $8.8 .11^{\mathrm{T}}$ were $75.9 \%$ and $79.8 \%$, respectively (Table 1), while the in silico DDH values between these strains were 21.3 and $23.5 \%$, respectively (Table 1). All these percentages were lower than $95-96 \%$ and $70 \%$, respectively, which are the defined cut-off limits for species delineation [71-75], and confirm that strain F20-122 ${ }^{\mathrm{T}}$ is genotypically distinct to any previously described species and should be assigned to a different species.

Table 1. Matrix of in silico DNA-DNA hybridization (DDH) and Ortho average nucleotide identity (OrthoANI) percentages between genomes of strain F20-122 ${ }^{\mathrm{T}}$ (showed in bold), species of the genus Natronomonas, and other related genera.

\begin{tabular}{|c|c|c|c|c|c|c|c|c|c|}
\hline In silico DDH & 1 & 2 & 3 & 4 & 5 & 6 & 7 & 8 & 9 \\
\hline 1 & & 75.9 & 79.8 & 71.8 & 71.3 & 72.5 & 71.6 & 72.7 & 72.6 \\
\hline 2 & 21.3 & & 76.5 & 71.5 & 71.2 & 72.1 & 71.6 & 72.2 & 72.4 \\
\hline 3 & 23.5 & 21.5 & & 72.2 & 71.9 & 72.9 & 71.9 & 72.6 & 72.8 \\
\hline 4 & 19.2 & 19.5 & 19.6 & & 73.8 & 74.0 & 72.9 & 74.0 & 73.9 \\
\hline 5 & 18.6 & 19.4 & 19.1 & 19.8 & & 73.1 & 72.1 & 73.3 & 73.0 \\
\hline 6 & 19.3 & 19.8 & 19.4 & 20.2 & 19.8 & & 74.8 & 75.1 & 74.5 \\
\hline 7 & 19.5 & 19.4 & 19.7 & 19.8 & 19.3 & 20.6 & & 73.9 & 73.3 \\
\hline 8 & 20.0 & 19.7 & 20.0 & 20.4 & 19.9 & 20.9 & 20.7 & & 74.6 \\
\hline 9 & 19.8 & 20.1 & 20.5 & 20.5 & 20.0 & 20.5 & 20.3 & 20.6 & \\
\hline
\end{tabular}

Strains: 1, Strain F20-122 ${ }^{\mathrm{T}}$ (QKNX00000000); 2, Natronomonas pharaonis DSM 2160 ${ }^{\mathrm{T}}(\mathrm{GCF}$-000026045); 3, Natronomonas moolapensis 8.8.11 ${ }^{\mathrm{T}}$ (GCF_000591055); 4, Halapricum salinum CBA $1105^{\mathrm{T}}$ (GCF_000755225); 5, Halorhabdus utahensis DSM $12940^{\mathrm{T}}$ (GCF_000023945); 6, Halomicrobium mukohatei DSM $12286^{\mathrm{T}}$ (GCF_000023965); 7, Haloarcula vallismortis ATCC $29715^{\mathrm{T}}$ (GCF_000337775); 8, Halosimplex carlsbadense 2-9-1 ${ }^{\mathrm{T}}$ (GCF_000337455); 9, Halorientalis regularis IBRC-M $10760^{\mathrm{T}}$ (GCF_900102305).

On the basis of the evidence obtained from the phylogenetic and phylogenomic analyses and the ANI and in silico DDH parameters, strain F20-122 ${ }^{\mathrm{T}}$ should be considered as a novel species within the genus Natronomonas, for which the name Natronomonas salsuginis sp. nov. is proposed.

\subsection{Phenotypic Characterization}

To describe strain $\mathrm{F} 20-122^{\mathrm{T}}$ as a new species, the complete phenotypic characterization of this strain was carried out and compared with that of Natronomonas moolapensis CECT $7526^{\mathrm{T}}$. Cells of strain F20- $122^{\mathrm{T}}$ were small coccobacilli shaped with a size of $1.0 \mu \mathrm{m}$ (width) by $1.2-2.5 \mu \mathrm{m}$ (length) (Figure $\mathrm{S} 1)$. Cells of the new isolate F20-122 ${ }^{\mathrm{T}}$ were nonmotile and Gram-stain-negative. Colonies were circular, entire, pink pigmented, and $0.2-0.3 \mathrm{~mm}$ in diameter on R2A25\% medium after 14 days of incubation at $37^{\circ} \mathrm{C}$. Strain $\mathrm{F} 20-122^{\mathrm{T}}$ is an extremely halophilic archaeon able to grow in media with $10 \%-30 \%$ $(w / v)$ total salts, with optimal growth at $25 \%(w / v)$ total salts. It is not able to grow in the absence of salts. The $\mathrm{pH}$ range for growth was 6.5-9.0, showing the optimal growth at $\mathrm{pH} 8.0$. Cells were able to grow from 25 to $50^{\circ} \mathrm{C}$, with the optimal growth at $37^{\circ} \mathrm{C}$. Catalase and oxidase activities were absent in strain $\mathrm{F} 20-122^{\mathrm{T}}$. The methyl red test was positive for the new isolate. Gelatin, starch, and aesculin were not hydrolyzed by strain $\mathrm{F} 20-122^{\mathrm{T}}$. Nitrate and nitrite were reduced. Other features of strain F20-122 ${ }^{\mathrm{T}}$ and the differential characteristics between strain F20-122 ${ }^{\mathrm{T}}$ and Natronomonas moolapensis CECT $7526^{\mathrm{T}}$ are given in the species description and Table 2. 
Table 2. Differential characteristics of strain $\mathrm{F} 20-122^{\mathrm{T}}$ and the type strain of the most closely related species of the genus, Natronomonas moolapensis CECT $7526^{\mathrm{T}}$.

\begin{tabular}{ccc}
\hline Characteristics & $\mathbf{1}$ & $\mathbf{2}$ \\
\hline Morphology & Coccoid & Rods or pleomorphic \\
Motility & - & $+^{*}$ \\
Cell size $(\mu \mathrm{m})$ & $1.0 \times 1.2-2.5$ & $0.7 \times 1.7^{*}$ \\
Colony size $(\mathrm{mm})$ & $0.2-0.3$ & $0.5-1.0$ \\
Colony pigmentation & Pink & Red \\
$\mathrm{NaCl}$ range (optimum) $(\%, w / v)$ & $10-30(25)$ & $14-36^{*}\left(18-20^{*}\right)$ \\
pH range (optimum) & $25-50(37)$ & $25-45^{*}\left(45^{*}\right)$ \\
Temperature range for growth $($ optimum $)\left({ }^{\circ} \mathrm{C}\right)$ & $6.5-9.0(8.0)$ & $5.5-8.5^{*}\left(7.0-7.5^{*}\right)$ \\
Utilization as sole carbon and energy source of: & & + \\
Butanol & - & + \\
Ethanol & - & + \\
D-Glucose & - & + \\
Glycerol & - & + \\
Propanol & - & + \\
Salicin & - & + \\
Isoleucine & - & 64.5 \\
\hline DNA G+C content $(m o l \%$, genome) & 63.2 & + \\
\hline
\end{tabular}

Strains: 1 , F20-122 ${ }^{\mathrm{T}} ; 2$, Natronomonas moolapensis CECT $7526^{\mathrm{T}}$. All data from this study, except ${ }^{*}$ which were obtained from the original description [5]. +, Positive; -, negative.

\subsection{Chemotaxonomic Characterization}

For the chemotaxonomic characterization, the total lipids of strain $\mathrm{F} 20-122^{\mathrm{T}}$ were extracted and compared with those from closely related neighbors, Natronomonas pharaonis CECT $4578^{\mathrm{T}}$ and Natronomonas moolapensis CECT $7526^{\mathrm{T}}$, and the reference strains Halobacterium salinarum DSM $3754^{\mathrm{T}}$ and Halorubrum saccharovorum DSM $1137^{\mathrm{T}}$. The HPTLC of the polar lipids (Figure S2) revealed that the polar lipid profile of strain $\mathrm{F} 20-122^{\mathrm{T}}$ consisted of phosphatidylglycerol phosphate methyl ester (PGP-Me) and phosphatidylglycerol (PG), both derived from $\mathrm{C}_{20} \mathrm{C}_{20}$ and $\mathrm{C}_{20} \mathrm{C}_{25}$ archaeol, and phosphatidylglycerol sulfate (PGS) as major lipids. Traces of biphosphatidylglycerol (BPG), minor phospholipids, and unidentified glycolipids were also detected. With the exception of the haloalkaliphilic species Natronomonas pharaonis CECT $4578^{\mathrm{T}}$, the profile of polar lipids of strain F20-122 ${ }^{\mathrm{T}}$ shares the major lipids described for all species of Natronomonas; the presence of double chain length $\mathrm{C}_{20} \mathrm{C}_{20}$ and $\mathrm{C}_{20} \mathrm{C}_{25}$ derived from biphosphatidylglycerol (BPG) is not typically found on neutrophilic haloarchaeal species. This profile shows the divergence and variability of the lipidic membrane composition; in fact, this genus includes alkaliphilic and neutrophilic species, suggesting the adaptability of these strains to thrive in environments with $\mathrm{pH}$ fluctuations.

\subsection{Genomic Characteristics}

The draft genome sequence of strain F20-122 ${ }^{\mathrm{T}}$ was obtained and compared with those of the type species of the genus, Natronomonas pharaonis DSM $2160^{\mathrm{T}}$, and the closest related species, Natronomonas moolapensis $8.8 .11^{\mathrm{T}}$. The main features of these genomes are shown in Table 3. The draft genome of strain F20-122 ${ }^{\mathrm{T}}$ was de novo assembled in a total of 13 contigs. The sequencing coverage depth of the entire genome was $531 \mathrm{X}$ with a N50 value of $675769 \mathrm{bp}$. This genome sequence is in accordance with the minimal standards for the use of genome data for the taxonomy of prokaryotes [76]. The genome size of strain F20-122 ${ }^{\mathrm{T}}$ was $2.9 \mathrm{Mb}$, identical to the genome of Natronomonas moolapensis $8.8 .11^{\mathrm{T}}$. The $\mathrm{G}+\mathrm{C}$ content (63.2 mol\%) and the number of rRNAs (3) and tRNAs (44) were also similar to those of the other Natronomonas species. Additional genomic characteristics are detailed in Table 3. 
Table 3. General features of the genomes of strain $\mathrm{F} 20-122^{\mathrm{T}}$ and closely related species of the genus Natronomonas used in this study.

\begin{tabular}{|c|c|c|c|}
\hline Feature & Strain F20-122 & $\begin{array}{c}\text { Natronomonas } \\
\text { pharaonis DSM } 2160^{\mathrm{T}}\end{array}$ & $\begin{array}{c}\text { Natronomonas } \\
\text { moolapensis } 8.8 .11^{\mathrm{T}}\end{array}$ \\
\hline Size $(\mathrm{Mb})$ & 2.9 & 2.6 & 2.9 \\
\hline Contigs & 13 & 1 & 1 \\
\hline Completeness (\%) & 97.7 & 99.7 & 99.5 \\
\hline $\mathrm{G}+\mathrm{C}(\mathrm{mol} \%)$ & 63.2 & 63.4 & 64.5 \\
\hline N50 (bp) & 675769 & 2595221 & 2912573 \\
\hline rRNA & 3 & 3 & 3 \\
\hline tRNA & 43 & 44 & 47 \\
\hline Accession number & QKNX00000000 & GCF_000026045 & GCF_000591055 \\
\hline
\end{tabular}

Furthermore, a Venn diagram was constructed (Figure S3) showing the number of shared genes between strain F20-122 ${ }^{\mathrm{T}}$, Natronomonas pharaonis DSM 2160 ${ }^{\mathrm{T}}$, and Natronomonas moolapensis 8.8.11 ${ }^{\mathrm{T}}$.

\subsection{Rhodopsin Analysis}

Rhodopsins are photoreactive proteins first discovered in Halobacterium salinarum [77] with two different functions: light-driven ion transport $\left(\mathrm{H}^{+}\right.$pump bacteriorhodopsin [78], $\mathrm{Cl}^{-}$pump halorhodopsin [79]) and phototaxis (sensory rhodopsins I and II [80,81]). Later on, distinct rhodopsins have also been identified in other organisms of the three domains of life, such as Natronomonas pharaonis, which has been a long-term target of study as a model organism for rhodopsin analyses due to its facile expression and purification in addition to other advantageous properties [82-87].

Considering the affiliation of strain F20-122 ${ }^{\mathrm{T}}$ with the genus Natronomonas, the presence of rhodopsin-like sequences on the genomes of strain F20-122 ${ }^{\mathrm{T}}$, Natronomonas moolapensis $8.8 .11^{\mathrm{T}}$, and Natronomonas pharaonis DSM $2160^{\mathrm{T}}$ was determined in detail (Figure 4). While halorhodopsins and sensory rhodopsins were found in Natronomonas pharaonis $[88,89]$ and Natronomonas moolapensis, haloarchaeal proton pumps were identified as the unique rhodopsin sequences for strain F20-122 (Figure 4). In addition, Natronomonas moolapensis also presented haloarchaeal proton pump rhodopsins, although situated in a different branch from strain F20-122 ${ }^{\mathrm{T}}$ (Figure 4B). The presence of haloarchaeal proton pumps for strain $\mathrm{F} 20-122^{\mathrm{T}}$ indicate a light-mediated ATP synthesis. These results are in accordance with previous metagenomic studies on hypersaline systems $[30,90]$ which brought to light the existence of a large number of rhodopsin coding genes, suggesting that light is widely used in these extreme habitats.

On the other side, depending on the major absorption light wavelength, rhodopsins could be sorted as "green-absorbing" or "blue-absorbing". This preference is determined by a single amino acid residue [91]. The rhodopsin-like sequence alignment identified in strain F20-122 ${ }^{\mathrm{T}}$ and other species of Natronomonas showed a leucine (L) amino acid residue in this position (Figure 4A), thus indicating a green spectrum absorption. 
A
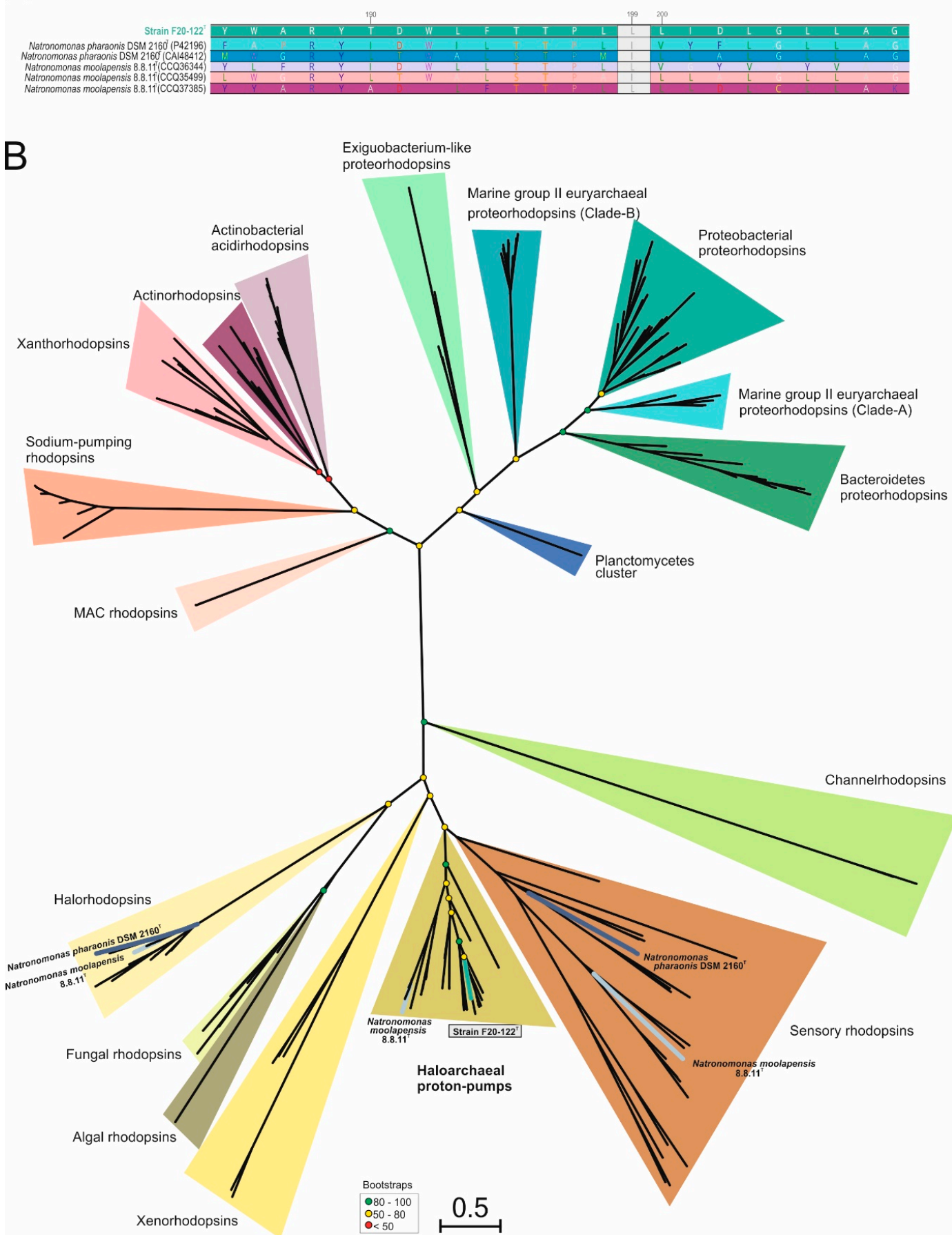

Figure 4. (A) Alignment comparison of rhodopsin sequences from species of the genus Natronomonas. Strain F20-122 ${ }^{\mathrm{T}}$ is highlighted in boldface. The green box exhibits the position 199 of the rhodopsin alignment, where the leucine (L) indicates a green absorption. (B) Maximum-likelihood phylogenetic tree based on 223 rhodopsin sequences. Colored branches were used to highlight rhodopsin sequences belonging to Natronomonas species. Bootstrap values on nodes are indicated by colored circles. Bar, 0.5 substitutions per nucleotide position. 


\section{Conclusions}

During the course of studies at different hypersaline environments located in the southwestern coast of Spain, a new extremely halophilic archaeon, strain $\mathrm{F} 20-122^{\mathrm{T}}$, phylogenetically related to the genus Natronomonas was isolated in pure culture and characterized using both new genomic and classical taxonomic methods in order to determine its precise affiliation. On the basis of this polyphasic taxogenomic study, it is concluded that strain $\mathrm{F} 20-122^{\mathrm{T}}$ constitutes a new species within the genus Natronomonas, for which the name Natronomonas salsuginis sp. nov. is proposed, the description of which is given below. Rhodopsin-encoding genes on the genome of this new haloarchaeon demonstrated the presence of proton pumps and the capacity for light-mediated ATP synthesis.

\section{Description of Natronomonas salsuginis sp. nov.}

Natronomonas salsuginis (sal.su'gi.nis. L. gen. n. salsuginis of brackish water, pertaining to the salty water).

Cells are Gram-stain-negative, nonmotile, coccoid, and 1.0 × 1.2-2.5 $\mu \mathrm{m}$. Does not grow anaerobically with L-arginine, DMSO, or potassium nitrate. Colonies are circular, entire, pink pigmented, and $0.2-0.3 \mathrm{~mm}$ in diameter on R2A25\% medium after 14 days of incubation at $37^{\circ} \mathrm{C}$. Extremely halophilic, able to grow in media with $10 \%-30 \%(w / v)$ salts, with optimal growth at $25 \%$ $(w / v)$ salts. No growth occurs in the absence of $\mathrm{NaCl}$. Able to grow in the $\mathrm{pH}$ range of 6.5-9.0 and from 25 to $50{ }^{\circ} \mathrm{C}$, with optimal growth at $\mathrm{pH} 8.0$ and at $37{ }^{\circ} \mathrm{C}$. Catalase and oxidase negative. Gelatin, starch, and aesculin are not hydrolyzed. Nitrate and nitrite are reduced. Urease and $\mathrm{H}_{2} \mathrm{~S}$ production are negative. Simmons' citrate and Voges-Proskauer tests are negative. Methyl red test is positive. Indole is not produced. Acid is produced from D-arabinose, D-fructose, D-glucose, and D-xylose but not from D-amygdalin, D,L-ethionine, glycerol, or D-sucrose. Starch, D-arabinose, D-cellobiose, fructose, D-glucose, lactose, maltose, D-mannose, L-raffinose, ribose, sucrose, D-trehalose, D-xylose, D-melezitose, butanol, dulcitol, ethanol, glycerol, D-mannitol, propanol, D-sorbitol, xylitol, methanol, benzoate, citrate, propionate, succinate, valerate, malate, pyruvate, or tartrate were not used as sole carbon and energy source. L-alanine, L-ornithine, L-glycine, L-lysine, L-threonine, and L-valine are used as sole carbon, nitrogen, and energy source but not L-arginine, asparagine, aspartic acid, L-cysteine, phenylalanine, glutamine, L-methionine, L-serine, tryptophan, and isoleucine. The major polar lipids are phosphatidylglycerol (PG), phosphatidylglycerol phosphate methyl ester (PGP-Me), and phosphatidylglycerol sulfated (PGS). Traces of biphosphatidylglycerol (BPG), other minor phospholipids, and unidentified glycolipids were also present. The DNA G+C content is $63.2 \mathrm{~mol} \%$ (genome).

The type strain is F20-122 ${ }^{\mathrm{T}}\left(=\mathrm{CCM} 8891^{\mathrm{T}}=\right.$ CECT $\left.9564^{\mathrm{T}}=\mathrm{JCM} 33320^{\mathrm{T}}\right)$, isolated from a marine saltern located in Isla Bacuta, Huelva, Spain.

The GenBank/EMBL/DDBJ accession number for the 16S rRNA and rpo $B^{\prime}$ gene sequences of Natronomonas salsuginis F20-122 ${ }^{\mathrm{T}}$ are MH424601 and MH454090, respectively, and that of the complete genome is QKNX00000000.

Supplementary Materials: The following are available online at http://www.mdpi.com/2076-2607/8/4/605/s1.

Author Contributions: A.D.-V. performed the isolation of the strain, the taxonomic characterization, and the genomic analyses. A.D.-V. prepared the draft manuscript and the tables and figures. C.S.-P. and A.V. designed the study and revised the manuscript. All authors read and approved the final manuscript.

Funding: This study was supported by the Spanish Ministry of Economy and Competitiveness (MINECO) through project CGL2017-83385-P and by Junta de Andalucía (Spain) (BIO-213, US-1263771), all including European (FEDER) funds.

Acknowledgments: A.D.V. was the recipient of a predoctoral fellowship from the Ministry of Education, Culture, and Sports, Spain. We thank P. Corral for her advice on the polar lipid analysis, A. Oren for his help on the nomenclature of the new species, and A. García-Roldán and M. Reina for technical assistance.

Conflicts of Interest: The authors declare no conflict of interest. 


\section{References}

1. Soliman, G.S.; Trüper, H.G. Halobacterium pharaonis sp. nov., a new, extremely haloalkaliphilic archaebacterium with low magnesium requirement. Zentralbl. Bakteriol. Mikrobiol. Hyg. I. Abt. Orig. C 1982, 3, 318-329. [CrossRef]

2. Tindall, B.; Ross, H.; Grant, W. Natronobacterium gen. nov. and Natronococcus gen. nov., two new genera of haloalkaliphilic archaebacteria. Syst. Appl. Microbiol. 1984, 5, 41-57. [CrossRef]

3. Kamekura, M.; Dyall-Smith, M.L.; Upasani, V.; Ventosa, A.; Kates, M. Diversity of alkaliphilic halobacteria: proposals for transfer of Natronobacterium vacuolatum, Natronobacterium magadii, and Natronobacterium pharaonis to Halorubrum, Natrialba, and Natronomonas gen. nov., respectively, as Halorubrum vacuolatum comb. nov., Natrialba magadii comb. nov., and Natronomonas pharaonis comb. nov., respectively. Int. J. Syst. Bacteriol. 1997, 47, 853-857. [CrossRef] [PubMed]

4. Parte, A.C. LPSN-List of Prokaryotic names with Standing in Nomenclature (bacterio.net), 20 years on. Int. J. Syst. Evol. Microbiol. 2018, 68, 1825-1829. [CrossRef]

5. Burns, D.G.; Janssen, P.H.; Itoh, T.; Minegishi, H.; Usami, R.; Kamekura, M.; Dyall-Smith, M.L. Natronomonas moolapensis sp. nov., non-alkaliphilic isolates recovered from a solar saltern crystallizer pond, and emended description of the genus Natronomonas. Int. J. Syst. Evol. Microbiol. 2009, 60, 1173-1176. [CrossRef]

6. Kim, T.-Y.; Kim, S.-J.; Park, S.-J.; Kim, J.-G.; Cha, I.-T.; Jung, M.-Y.; Lee, S.-A.; Roh, S.W.; Yim, K.J.; Itoh, T.; et al. Natronomonas gomsonensis sp. nov., isolated from a solar saltern. Antonie van Leeuwenhoek 2013, 104, 627-635. [CrossRef]

7. Stan-Lotter, H.; Doppler, E.; Jarosch, M.; Radax, C.; Gruber, C.; Inatomi, K.-I. Isolation of a chymotrypsinogen B-like enzyme from the archaeon Natronomonas pharaonis and other halobacteria. Extremophiles 1999, 3, 153-161. [CrossRef]

8. Cao, Y.; Liao, L.; Xu, X.-W.; Oren, A.; Wang, C.; Zhu, X.-F.; Wu, M. Characterization of alcohol dehydrogenase from the haloalkaliphilic archaeon Natronomonas pharaonis. Extremophiles 2008, 12, 471-476. [CrossRef]

9. Cao, Y.; Liao, L.; Xu, X.-W.; Oren, A.; Wu, M. Aldehyde dehydrogenase of the haloalkaliphilic archaeon Natronomonas pharaonis and its function in ethanol metabolism. Extremophiles 2008, 12, 849-854. [CrossRef]

10. Gradinaru, V.; Thompson, K.R.; Deisseroth, K. eNpHR: A Natronomonas halorhodopsin enhanced for optogenetic applications. Brain Cell Biol. 2008, 36, 129-139. [CrossRef]

11. Chen, X.-R.; Huang, Y.-C.; Yi, H.-P.; Yang, C.-S. A unique light-driven proton transportation signal in halorhodopsin from Natronomonas pharaonis. Biophys. J. 2016, 111, 2600-2607. [CrossRef] [PubMed]

12. Kato, H.E.; Inoue, K.; Kandori, H.; Nureki, O. The light-driven sodium ion pump: a new player in rhodopsin research. BioEssays 2016, 38, 1274-1282. [CrossRef] [PubMed]

13. Amtul, Z.; Aziz, A.A. Microbial proteins as novel industrial biotechnology hosts to treat epilepsy. Mol. Neurobiol. 2016, 54, 8211-8224. [CrossRef] [PubMed]

14. Sakajiri, Y.; Sugano, E.; Watanabe, Y.; Sakajiri, T.; Tabata, K.; Kikuchi, T.; Tomita, H. Natronomonas pharaonis halorhodopsin Ser81 plays a role in maintaining chloride ions near the Schiff base. Biochem. Biophys. Res. Commun. 2018, 503, 2326-2332. [CrossRef] [PubMed]

15. Fujisawa, T.; Kiyota, H.; Kikukawa, T.; Unno, M. Low-temperature Raman spectroscopy of halorhodopsin from Natronomonas pharaonis: structural discrimination of blue-shifted and red-shifted photoproducts. Biochemistry 2019, 58, 4159-4167. [CrossRef]

16. Burns, D.G.; Camakaris, H.M.; Janssen, P.H.; Dyall-Smith, M. Combined use of cultivation-dependent and cultivation-independent methods indicates that members of most haloarchaeal groups in an Australian crystallizer pond are cultivable. Appl. Environ. Microbiol. 2004, 70, 5258-5265. [CrossRef]

17. Sime-Ngando, T.; Lucas, S.; Robin, A.; Tucker, K.; Colombet, J.; Bettarel, Y.; Desmond, E.; Gribaldo, S.; Forterre, P.; Breitbart, M.; et al. Diversity of virus-host systems in hypersaline Lake Retba, Senegal. Environ. Microbiol. 2010, 13, 1956-1972. [CrossRef]

18. Wang, X.; Han, Z.; Bai, Z.; Tang, J.; Ma, A.; He, J.; Zhuang, G. Archaeal community structure along a gradient of petroleum contamination in saline-alkali soil. J. Environ. Sci. 2011, 23, 1858-1864. [CrossRef]

19. Ghai, R.; Pašić, L.; Fernandez, A.B.; Martin-Cuadrado, A.-B.; Mizuno, C.M.; McMahon, K.D.; Papke, R.T.; Stepanauskas, R.; Rodriguez-Brito, B.; Rohwer, F.; et al. New abundant microbial groups in aquatic hypersaline environments. Sci. Rep. 2011, 1, 135. [CrossRef] 
20. Boujelben, I.; Gomariz, M.; Martinez-Garcia, M.; Santos, F.; Peña, A.; Lopez, C.; Anton, J.; Maalej, S. Spatial and seasonal prokaryotic community dynamics in ponds of increasing salinity of Sfax solar saltern in Tunisia. Antonie van Leeuwenhoek 2012, 101, 845-857. [CrossRef]

21. Oueriaghli, N.; Béjar, V.; Quesada, E.; Martínez-Checa, F. Molecular ecology techniques reveal both spatial and temporal variations in the diversity of archaeal communities within the athalassohaline environment of Rambla Salada, Spain. Microb. Ecol. 2013, 66, 297-311. [CrossRef]

22. Fernandez, A.B.; Ghai, R.; Martin-Cuadrado, A.-B.; Sanchez-Porro, C.; Rodriguez-Valera, F.; Ventosa, A. Prokaryotic taxonomic and metabolic diversity of an intermediate salinity hypersaline habitat assessed by metagenomics. FEMS Microbiol. Ecol. 2014, 88, 623-635. [CrossRef] [PubMed]

23. Sankaranarayanan, K.; Lowenstein, T.K.; Timofeeff, M.N.; Schubert, B.A.; Lum, J.K. Characterization of ancient DNA supports long-term survival of haloarchaea. Astrobiology 2014, 14, 553-560. [CrossRef] [PubMed]

24. Tazi, L.; Breakwell, D.P.; Harker, A.R.; Crandall, K.A. Life in extreme environments: microbial diversity in Great Salt Lake, Utah. Extremophiles 2014, 18, 525-535. [CrossRef] [PubMed]

25. Sun, W.; Li, J.; Jiang, L.; Sun, Z.; Fu, M.; Peng, X. Profiling microbial community structures across six large oilfields in China and the potential role of dominant microorganisms in bioremediation. Appl. Microbiol. Biotechnol. 2015, 99, 8751-8764. [CrossRef]

26. Navarro-Noya, Y.E.; Valenzuela-Encinas, C.; Sandoval-Yuriar, A.; Jiménez-Bueno, N.G.; Marsch, R.; Dendooven, L. Archaeal communities in a heterogeneous hypersaline-alkaline soil. Archaea 2015, 2015, 1-11. [CrossRef]

27. Dalvi, S.; Youssef, N.H.; Fathepure, B.Z. Microbial community structure analysis of a benzoate-degrading halophilic archaeal enrichment. Extremophiles 2016, 20, 311-321. [CrossRef]

28. Haferburg, G.; Gröning, J.; Schmidt, N.; Kummer, N.-A.; Erquicia, J.C.; Schlömann, M. Microbial diversity of the hypersaline and lithium-rich Salar de Uyuni, Bolivia. Microbiol. Res. 2017, 199, 19-28. [CrossRef]

29. Han, R.; Zhang, X.; Liu, J.; Long, Q.; Chen, L.; Liu, D.; Zhu, D. Microbial community structure and diversity within hypersaline Keke Salt Lake environments. Can. J. Microbiol. 2017, 63, 895-908. [CrossRef]

30. Vera-Gargallo, B.; Ventosa, A. Metagenomic insights into the phylogenetic and metabolic diversity of the prokaryotic community dwelling in hypersaline soils from the Odiel Saltmarshes (SW Spain). Genes 2018, 9, 152. [CrossRef]

31. Couto-Rodríguez, R.L.; Montalvo-Rodríguez, R. Temporal analysis of the microbial community from the crystallizer ponds in Cabo Rojo, Puerto Rico, using metagenomics. Genes 2019, 10, 422. [CrossRef] [PubMed]

32. Marmur, J. A procedure for the isolation of deoxyribonucleic acid from micro-organisms. J. Mol. Biol. 1961, 3, 208-218. [CrossRef]

33. Sambrook, J.; Russell, D.W. Molecular Cloning: A Laboratory Manual III.; Cold Spring Harbor Laboratory Press: Cold Spring Harbor, NY, USA, 2001; ISBN 9781936113415.

34. Delong, E.F. Archaea in coastal marine environments. Proc. Natl. Acad. Sci. USA 1992, 89, 5685-5689. [CrossRef] [PubMed]

35. Arahal, D.R.; Dewhirst, F.E.; Paster, B.J.; Volcani, B.E.; Ventosa, A. Phylogenetic analyses of some extremely halophilic archaea isolated from Dead Sea water, determined on the basis of their 16S rRNA sequences. Appl. Environ. Microbiol. 1996, 62, 3779-3786. [CrossRef] [PubMed]

36. Fullmer, M.; Soucy, S.M.; Swithers, K.S.; Makkay, A.M.; Wheeler, R.; Ventosa, A.; Gogarten, J.P.; Papke, R.T. Population and genomic analysis of the genus Halorubrum. Front. Microbiol. 2014, 5, 140. [CrossRef] [PubMed]

37. Yoon, S.-H.; Ha, S.-M.; Kwon, S.; Lim, J.; Kim, Y.; Seo, H.; Chun, J. Introducing EzBioCloud: A taxonomically united database of $16 \mathrm{~S}$ rRNA gene sequences and whole-genome assemblies. Int. J. Syst. Evol. Microbiol. 2017, 67, 1613-1617. [CrossRef]

38. Altschul, S.F.; Gish, W.; Miller, W.; Myers, E.W.; Lipman, D.J. Basic local alignment search tool. J. Mol. Biol. 1990, 215, 403-410. [CrossRef]

39. Ludwig, W.; Strunk, O.; Westram, R.; Richter, L.; Meier, H.; Buchner, A.; Lai, T.; Steppi, S.; Jobb, G.; Förster, W.; et al. ARB: A software environment for sequence data. Nucleic Acids Res. 2004, 32, 1363-1371. [CrossRef]

40. Fitch, W.M. Toward defining the course of evolution: Minimum change for a specific tree topology. Syst. Biol. 1971, 20, 406-416. [CrossRef] 
41. Saitou, N.; Nei, M. The neighbor-joining method: A new method for reconstructing phylogenetic trees. Mol. Biol. Evol. 1987, 4, 406-425. [CrossRef]

42. Felsenstein, J. Evolutionary trees from DNA sequences: A maximum likelihood approach. J. Mol. Evol. 1981, 17, 368-376. [CrossRef] [PubMed]

43. Felsenstein, J. Confidence limits on phylogenies: An approach using the bootstrap. Evolution 1985, 39, 783-791. [CrossRef] [PubMed]

44. Tamura, K.; Stecher, G.; Peterson, D.; Filipski, A.; Kumar, S. MEGA6: Molecular Evolutionary Genetics Analysis version 6. Mol. Biol. Evol. 2013, 30, 2725-2729. [CrossRef] [PubMed]

45. Edgar, R.C. MUSCLE: A multiple sequence alignment method with reduced time and space complexity. BMC Bioinform. 2004, 5, 113. [CrossRef]

46. Heberle, H.; Meirelles, G.V.; Da Silva, F.R.; Telles, G.P.; Minghim, R. InteractiVenn: A web-based tool for the analysis of sets through Venn diagrams. BMC Bioinform. 2015, 16, 169. [CrossRef]

47. Bankevich, A.; Nurk, S.; Antipov, D.; Gurevich, A.A.; Dvorkin, M.; Kulikov, A.S.; Lesin, V.M.; Nikolenko, S.I.; Pham, S.; Prjibelski, A.D.; et al. SPAdes: A new genome assembly algorithm and its applications to single-cell sequencing. J. Comput. Biol. 2012, 19, 455-477. [CrossRef]

48. Parks, D.H.; Imelfort, M.; Skennerton, C.; Hugenholtz, P.; Tyson, G.W. CheckM: Assessing the quality of microbial genomes recovered from isolates, single cells, and metagenomes. Genome Res. 2015, 25, 1043-1055. [CrossRef]

49. Gurevich, A.; Saveliev, V.; Vyahhi, N.; Tesler, G. QUAST: Quality assessment tool for genome assemblies. Bioinformatics 2013, 29, 1072-1075. [CrossRef]

50. Tatusova, T.; DiCuccio, M.; Badretdin, A.; Chetvernin, V.; Nawrocki, E.P.; Zaslavsky, L.; Lomsadze, A.; Pruitt, K.D.; Borodovsky, M.; Ostell, J. NCBI prokaryotic genome annotation pipeline. Nucleic Acids Res. 2016, 44, 6614-6624. [CrossRef]

51. Lee, I.; Kim, Y.O.; Park, S.-C.; Chun, J. OrthoANI: An improved algorithm and software for calculating average nucleotide identity. Int. J. Syst. Evol. Microbiol. 2016, 66, 1100-1103. [CrossRef]

52. Meier-Kolthoff, J.; Auch, A.F.; Klenk, H.-P.; Göker, M. Genome sequence-based species delimitation with confidence intervals and improved distance functions. BMC Bioinform. 2013, 14, 60. [CrossRef] [PubMed]

53. Auch, A.F.; Klenk, H.-P.; Göker, M. Standard operating procedure for calculating genome-to-genome distances based on high-scoring segment pairs. Stand. Genom. Sci. 2010, 2, 142-148. [CrossRef] [PubMed]

54. Oren, A.; Ventosa, A.; Grant, W.D. Proposed minimal standards for description of new taxa in the order Halobacteriales. Int. J. Syst. Bacteriol. 1997, 47, 233-238. [CrossRef]

55. Dussault, H.P. An improved technique for staining red halophilic bacteria. J. Bacteriol. 1955, 70, 484-485. [CrossRef]

56. Scorpio, R. Fundamentals of Acids, Bases, Buffers and Their Application to Biochemical Systems; Kendall/Hunt Publishing: Dubuque, IA, USA, 2000.

57. Kovacs, N. Identification of Pseudomonas pyocyanea by the oxidase reaction. Nature 1956, 178, 703. [CrossRef]

58. Barrow, G.I.; Feltham, R.K.A. Cowan and Steel's Manual for the Identification of Medical Bacteria; Cambridge University Press: Cambridge, UK, 2003; ISBN 9780521543.

59. Gerhardt, P.; Murray, R.G.; Wood, W.A.; Krieg, N. Methods for General and Molecular Bacteriology; American Society for Microbiology: Washington, DC, USA, 1994.

60. Smibert, R.M.; Krieg, N.R. General characterization. In Manual of Methods for General Bacteriology; Gerhardt, P., Murray, R.G.E., Costilow, R.N., Nester, E.W., Wood, W.A., Krieg, N., Eds.; American Society for Microbiology: Washington, DC, USA, 1981; pp. 409-443.

61. Clarke, P.H. Hydrogen sulphide production by bacteria. J. Gen. Microbiol. 1953, 8, 397-407. [CrossRef]

62. Ventosa, A.; Quesada, E.; Rodriguez-Valera, F.; Ruiz-Berraquero, F.; Ramos-Cormenzana, A. Numerical taxonomy of moderately halophilic Gram-negative rods. Microbiology 1982, 128, 1959-1968. [CrossRef]

63. Corcelli, A.; Lobasso, S. 25 Characterization of lipids of halophilic archaea. Methods Microbiol. 2006, 35, 585-613. [CrossRef]

64. Angelini, R.; Corral, P.; Lopalco, P.; Ventosa, A.; Corcelli, A. novel ether lipid cardiolipins in archaeal membranes of extreme haloalkaliphiles. Biochim. Biophys. Acta 2012, 1818, 1365-1373. [CrossRef]

65. Kates, M. Techniques of Lipidology: Isolation, Analysis, and Identification of Lipids; Elsevier: Amsterdam, The Netherlands, 1986; ISBN 0444807322. 
66. Eddy, S.R. Accelerated profile HMM searches. PLoS Comput. Biol. 2011, 7, e1002195. [CrossRef]

67. Katoh, K.; Standley, D.M. MAFFT multiple sequence alignment software version 7: improvements in performance and usability. Mol. Biol. Evol. 2013, 30, 772-780. [CrossRef] [PubMed]

68. Price, M.N.; Dehal, P.S.; Arkin, A.P. FastTree 2-approximately maximum-likelihood trees for large alignments. PLoS ONE 2010, 5, e9490. [CrossRef] [PubMed]

69. Boucher, Y.F.; Douady, C.J.; Sharma, A.K.; Kamekura, M.; Doolittle, W.F. Intragenomic heterogeneity and intergenomic recombination among haloarchaeal rRNA Genes. J. Bacteriol. 2004, 186, 3980-3990. [CrossRef] [PubMed]

70. Sun, D.-L.; Jiang, X.; Wu, Q.L.; Zhou, N.-Y. Intragenomic heterogeneity of 16S rRNA genes causes overestimation of prokaryotic diversity. Appl. Environ. Microbiol. 2013, 79, 5962-5969. [CrossRef] [PubMed]

71. Stackebrandt, E.; Frederiksen, W.; Garrity, G.M.; Grimont, P.A.D.; Kämpfer, P.; Maiden, M.C.J.; Nesme, X.; Rosselló-Mora, R.; Swings, J.; Trüper, H.G.; et al. Report of the ad hoc committee for the re-evaluation of the species definition in bacteriology. Int. J. Syst. Evol. Microbiol. 2002, 52, 1043-1047.

72. Konstantinidis, K.T.; Tiedje, J.M. Genomic insights that advance the species definition for prokaryotes. Proc. Natl. Acad. Sci. USA 2005, 102, 2567-2572. [CrossRef]

73. Goris, J.; Klappenbach, J.A.; Vandamme, P.; Coenye, T.; Konstantinidis, K.T.; Tiedje, J.M. DNA-DNA hybridization values and their relationship to whole-genome sequence similarities. Int. J. Syst. Evol. Microbiol. 2007, 57, 81-91. [CrossRef]

74. Richter, M.; Rossello-Mora, R. Shifting the genomic gold standard for the prokaryotic species definition. Proc. Natl. Acad. Sci. USA 2009, 106, 19126-19131. [CrossRef]

75. Konstantinidis, K.T.; Rossello-Mora, R.; Amann, R.I. Uncultivated microbes in need of their own taxonomy. ISME J. 2017, 11, 2399-2406. [CrossRef]

76. Chun, J.; Oren, A.; Ventosa, A.; Christensen, H.; Arahal, D.R.; Da Costa, M.S.; Rooney, A.; Yi, H.; Xu, X.-W.; De Meyer, S.; et al. Proposed minimal standards for the use of genome data for the taxonomy of prokaryotes. Int. J. Syst. Evol. Microbiol. 2018, 68, 461-466. [CrossRef]

77. Oesterhelt, D.; Stoeckenius, W. Rhodopsin-like protein from the purple membrane of Halobacterium halobium. Nat. New Biol. 1971, 233, 149-152. [CrossRef] [PubMed]

78. Oesterhelt, D.; Stoeckenius, W. Functions of a new photoreceptor membrane. Proc. Natl. Acad. Sci. USA 1973, 70, 2853-2857. [CrossRef] [PubMed]

79. Schobert, B.; Lanyi, J.K. Halorhodopsin is a light-driven chloride pump. J. Biol. Chem. 1982, 257, 10306-10313. [PubMed]

80. Bogomolni, R.A.; Spudich, J.L. Identification of a third rhodopsin-like pigment in phototactic Halobacterium halobium. Proc. Natl. Acad. Sci. USA 1982, 79, 6250-6254. [CrossRef]

81. Takahashi, T.; Tomioka, H.; Kamo, N.; Kobatake, Y. A photosystem other than PS370 also mediates the negative phototaxis of Halobacterium halobium. FEMS Microbiol. Lett. 1985, 28, 161-164. [CrossRef]

82. Maiti, T.K.; Engelhard, M.; Sheves, M. Retinal-protein interactions in halorhodopsin from Natronomonas pharaonis: binding and retinal thermal isomerization catalysis. J. Mol. Biol. 2009, 394, 472-484. [CrossRef]

83. Kanada, S.; Takeguchi, Y.; Murakami, M.; Ihara, K.; Kouyama, T. Crystal structures of an O-like blue form and an anion-free yellow form of pharaonis halorhodopsin. J. Mol. Biol. 2011, 413, 162-176. [CrossRef]

84. Tamogami, J.; Iwano, K.; Matsuyama, A.; Kikukawa, T.; Demura, M.; Nara, T.; Kamo, N. The effects of chloride ion binding on the photochemical properties of sensory rhodopsin II from Natronomonas pharaonis. J. Photochem. Photobiol. B Biol. 2014, 141, 192-201. [CrossRef]

85. Kikukawa, T.; Kusakabe, C.; Kokubo, A.; Tsukamoto, T.; Kamiya, M.; Aizawa, T.; Ihara, K.; Kamo, N.; Demura, M. Probing the $\mathrm{Cl}^{-}$pumping photocycle of pharaonis halorhodopsin: examinations with bacterioruberin, an intrinsic dye, and membrane potential-induced modulation of the photocycle. Biochim. Biophys. Acta 2015, 1847, 748-758. [CrossRef]

86. Chan, S.K.; Kawaguchi, H.; Kubo, H.; Murakami, M.; Ihara, K.; Maki, K.; Kouyama, T. Crystal structure of the 11-cis isomer of Pharaonis halorhodopsin: structural constraints on interconversions among different isomeric states. Biochemistry 2016, 55, 4092-4104. [CrossRef]

87. Engelhard, C.; Chizhov, I.; Siebert, F.; Engelhard, M. Microbial halorhodopsins: light-driven chloride pumps. Chem. Rev. 2018, 118, 10629-10645. [CrossRef] [PubMed]

88. Kamekura, M. Diversity of extremely halophilic bacteria. Extremophiles 1998, 2, 289-295. [CrossRef] [PubMed] 
89. Falb, M.; Pfeiffer, F.; Palm, P.; Rodewald, K.; Hickmann, V.; Tittor, J.; Oesterhelt, D. Living with two extremes: conclusions from the genome sequence of Natronomonas pharaonis. Genome Res. 2005, 15, 1336-1343. [CrossRef]

90. Fernandez, A.B.; Vera-Gargallo, B.; Sanchez-Porro, C.; Ghai, R.; Papke, R.T.; Rodríguez-Valera, F.; Ventosa, A. Comparison of prokaryotic community structure from Mediterranean and Atlantic saltern concentrator ponds by a metagenomic approach. Front. Microbiol. 2014, 5, 1-12. [CrossRef] [PubMed]

91. Man, D.; Wang, W.; Sabehi, G.; Aravind, L.; Post, A.F.; Massana, R.; Spudich, E.N.; Spudich, J.L.; Beja, O. Diversification and spectral tuning in marine proteorhodopsins. EMBO J. 2003, 22, 1725-1731. [CrossRef] [PubMed]

(C) 2020 by the authors. Licensee MDPI, Basel, Switzerland. This article is an open access article distributed under the terms and conditions of the Creative Commons Attribution (CC BY) license (http://creativecommons.org/licenses/by/4.0/). 